NASA Technical Memorandum 88974

\title{
Fatigue Failure of Regenerator Screens in a High Frequency Stirling Engine
}

David R. Hull, Donald L. Alger,

Thomas J. Moore, and Coulson M. Scheuermann Lewis Research Center

Cleveland, Ohio

March 1987

\section{NMSA}




\section{DISCLAIMER}

This report was prepared as an account of work sponsored by an agency of the United States Government. Neither the United States Government nor any agency Thereof, nor any of their employees, makes any warranty, express or implied, or assumes any legal liability or responsibility for the accuracy, completeness, or usefulness of any information, apparatus, product, or process disclosed, or represents that its use would not infringe privately owned rights. Reference herein to any specific commercial product, process, or service by trade name, trademark, manufacturer, or otherwise does not necessarily constitute or imply its endorsement, recommendation, or favoring by the United States Government or any agency thereof. The views and opinions of authors expressed herein do not necessarily state or reflect those of the United States Government or any agency thereof. 


\section{DISCLAIMER}

Portions of this document may be illegible in electronic image products. Images are produced from the best available original document. 
NASA Technical Memorandum 88974

\section{Fatigue Failure of Regenerator Screens in a High Frequency Stirling Engine}

David R. Hull, Donald L. Alger,

Thomas J. Moore, and Coulson M. Scheuermann

Lewis Research Center

Cleveland, Ohio

March 1987

\section{NMSA}


FATIGUE FAILURE OF REGENERATOR SCREENS IN A HIGH

FREQUENCY STIRLING ENGINE

David R. Hull, Donald L. Alger, Thomas J. Moore,

and Coulson M. Scheuermann

National Aeronautics and Space Administration

Lewis Research Center

Cleveland, Ohio 44135

\section{SUMMARY}

Failure of Stirling Space Power Demonstrator Engine (SPDE) regenerator screens was investigated. After several hours of operation the SPDE was shut down for inspection and upon removal of the regenerator screens, debris of an unknown origin was discovered along with considerable cracking of the screens in localized areas. Metallurgical analysis of the debris determined it to be cracked of $f$-deformed pieces of the $41 \mu \mathrm{m}$ thickness Type 304 stainless steel wire screen. Scanning electron microscopy of the cracked screens revealed failures occurring at wire crossovers and fatigue striations on the fracture surface of the wires. Thus, the screen failure can be characterized as a fatigue failure of the wires. The crossovers were determined to contain a 30 percent reduction in wire thickness and a highly worked microstructure occurring from the manufacturing process of the wire screens. Later it was found that reduction in wire thickness occurred because the screen fabricator had subjected the screen to a light cold-roll process after weaving. Instal. lation of this screen left a clearance in the regenerator allowing the screens to move. The combined effects of the reduction in wire thickness, stress con centration (caused by screen movement), and highly worked microstructure at the wire crossovers led to the fatigue failure of the screens.

\section{INTRODUCTION}

The Stirling Space Power Demonstrator Engine (SPDE) is currently undergoing testing at Mechanical Technology Inc. (MTI) as part of the SP-100 Advanced Technology Program being conducted by NASA Lewis Research Center. The SPDE is a Stirling engine with a two cylinder, opposed-piston/alternator configuration designed to achieve a $25 \mathrm{~kW}$ electrical power output. Two major advances beyond existing free-piston stirling engine technology which were necessary to meet the space objectives were an increase in engine operating pressure from 6 to $15 \mathrm{MPa}$, and an increase in engine operating frequency from 60 to $105 \mathrm{~Hz}$.

The heater, cooler, and regenerator heat exchanger geometries were opt $i$. mized by Stirling engine computer codes at the design power level for maximum system efficiency. The impact of higher frequency caused an increase in regenerator frontal area and a reduction in regenerator length. An annular regenerator configuration was selected which consisted of a stack of individual unsintered wire screens which were sandwiched between the heater and cooler tube sheets. The heater and cooler were of a tube-in-shell design, with the engine working gas passing through the tubes. Unsintered regenerator screens were chosen over sintered screens because previous testing of low frequency engines had shown that the unsintered screens provided a slight engine efficiency advantage over the sintered screens.

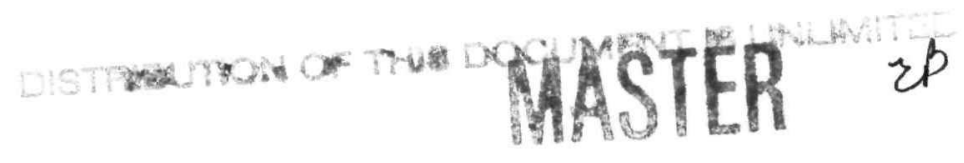


After several hours of SPDE operation at the design operating pressure of $15 \mathrm{MPa}$ and frequency of $105 \mathrm{~Hz}$, the engine was shutdown and disassembled because a slight rub had occurred between the displacer and its mating cylinder. Upon removal of the regenerator screens, considerable cracking of the screens was noted and there were loose particles and small pieces of screen found both on the mating heater tube sheet and between the screens. This report describes the results of a failure investigation of the regenerator screens and associated debris by metallurgical analysis.

\section{SPACE POWER DEMONSTRATOR ENGINE}

The SPDE is currently under test by MTI. Figure 1 shows the engine, sus pended from the ceiling by four flexible straps. The flexible suspension was used to demonstrate that there was no discernible vibration during operation. The engine is about $1.25 \mathrm{~m}$ in length and $0.33 \mathrm{~m}$ in diameter. A cutaway of the engine is shown in figure 2. The working fluid is helium. Heat is supplied by molten salt which flows through the shell of the heater. An ethyleneglycol solution is circulated through the shell of the cooler. A detalled description of the engine and its operation is given in reference 1 . Only a brief description of its operation is presented here.

In the Stirling engine operation, the displacer oscillates axially and shuttles the helium back and forth through the heater, regenerator, and cooler. Heat is continuously added to the helium as it passes through the heater tubes. Heat is absorbed from and rejected to the regenerator matrix during each half of the flow cycle. Heat is continually removed from the helium as it passes through the cooler tubes. It is the variation in helium temperature caused by the shuttling of helium back and forth through the heat exchangers, coupled with the inertial forces of the moving displacer and piston, that creates the pressure wave which acts upon the face of the power piston to produce work. The power piston oscillates axially as it extracts energy from the pressure wave. Magnets in the plunger assembly, attached to the piston, induce a voltage in the coil of the stator from which electrical power is extracted.

\section{STIRIING ENGINE REGENERATORS}

The regenerator is one of the most important components of a stirling engine. It can be visualized as a thermal sponge or capacitor whose function is to absorb and desorb large amounts of heat during each engine cycle. During the flow of helium gas from the heater to the cooler, the hot gas entering the regenerator transfers its heat to the metal screen matrix, which acts as a heat sink. During the subsequent flow of helium from the cooler to the heater, the cold helium entering the regenerator is heated by the screen matrix, which acts as a heat source. Energy flow in the regenerator is very high, usually three or four times the energy flow in the heater (ref. 2).

The matrix of the SPDE regenerator consists of layers of woven Type 304 stainless steel screen. Parameters that influence the screen regenerator effectiveness - and therefore engine performance--are mesh size, wire thickness, volume, frontal area, and the helium-to-screen heat transfer coefficient (ref. 3). 
The regenerator matrix for each of the opposed engines of the SPDE is made up of a stack of 350 annular shaped, 200 mesh, woven screens with a wire thick ness of $41 \mu \mathrm{m}$. A stack of new regenerator screens is shown in figure 3 . The screens are pressed into the annular space at the base of the heater shown in figure 4, between the displacer cylinder and heater housing. The screens fill a regenerator length of about $2.54 \mathrm{~cm}$.

\section{FAILURE OF THE SPDE REGENERATORS}

The SPDE was operated at approximately $7.5 \mathrm{MPa}$ (at about $70 \mathrm{~Hz}$ ) for a total of $75.4 \mathrm{hr}$. Engine operating pressure was then increased to the design point of $150 \mathrm{MPa} / 105 \mathrm{~Hz}$ and testing was continued for another $4.5 \mathrm{hr}$. At the design point, the power output of the engine was about half of the predicted design power level. The reason for the power shortfall was not known at this time.

Upon disassembly of the engine, a considerable quantity of debris was found in the regenerators. Two types of debris were collected based on their location in the regenerator. One type was collected from the heater tube sheet that interfaces with the hot side of the regenerator. The second was collected from between the regenerator screens as the regenerator stack was disassembled screen by screen. Both types of debris were found to be magnetic. It was speculated originally that the debris might be pure nickel, from a coating on the piston, or pieces of the magnets in the plunger assembly.

Figure 5 is a photograph of the top screen surface of the regenerator. Top screen refers to the regenerator screen surface that faces the heater tube sheet at the hot end of the regenerator. Figure $5(b)$ shows the surface of a screen that was deeper down in the regenerator stack-.approximately two-thirds through the 350 screen stack. A higher magnification photograph of the top screen (fig. 6) shows more clearly the severe damage done to the screen and the presence of particles filling some of the screen openings. Specimens of these regenerator screens and the collected debris were prepared for metallur. gical examination.

\section{METALLURGICAL ANALYSIS}

The scanning electron microscope (SEM) was used to examine the screens in three conditions; as-received, inside screen, and top screen (fig. 7). An as-received piece of screen is examined throughout the analysis to serve as a reference. Figure $7(a)$ shows the as-received screen to have flattened wires at crossovers due to the manufacturing process of the screens. After being run in the engine, a screen from inside the stack (fig. 7(b)) shows additional uniform damage (cratering) and "chips" of material on the wires. The top screen, closest to the heater tubes shows severe damage to the wires ( fig. $7(\mathrm{c})$ ), including fractures at crossovers, uniform cratering, pieces of wire missing, and wire debris filling screen openings. In looking at the fractured wires more closely there is evidence of fatigue striations ( $\mathrm{fig} .8(\mathrm{a})$ to (b)) and fatigue cracking at the saddle points of the crossover (fig. $8(\mathrm{c}$ ) to $(d))$. 
Debris found in the engine was examined by SEM and identified as Type 304 stainless steel by $x$-ray energy dispersive spectroscopy (XEDS). X-ray diffraction of the debris, as-run-in-engine screens, and as-received screens, were found to consist of both face-centered-cubic ( $a=0.3607 \mathrm{~nm}$ ) and body-centeredcubic $(a=0.287 \mathrm{~nm})$ phases. The debris found in between the regenerator screens is shown to be pieces of screen (fig. 9(a) to (b)). The debris found outside the regenerator is made up of stainless steel "chips" less than $20 \mu \mathrm{m}$ in size (fig. $9(\mathrm{c})$ ). The "chips" arise from the deformation of the wire, a chip being fractured from a wire can be seen in figure $9(b)$. Due to their size they were able to pass through the screen openings and exit the regenerator.

Microstructures of the as-received and run-in-engine screens were examined by performing standard metallographic techniques. Optical micrographs show the wire crossovers to contain a highly worked microstructure, while away from the crossovers the microstructure consisted of equiaxed grains (fig. 10). Transverse sections of the wires showed the worked microstructure to exist across the full thickness of the wires at crossovers (fig. 10(c)). No variation in microstructure was observed between the as-received and run-in-engine screens.

Microhardness measurements showed the highly worked microstructure at crossovers to be harder than the equiaxed structure between crossovers (fig. $11(a)$ ). A comparison of hardnesses between as-received and run-inengine is shown in table I. Hardness of the undeformed wire was the same for both conditions. The deformed wire in the run-in-engine sample showed a slight decrease in hardness when compared to the as-received sample. Microhardness measurements were made on transverse sections for the comparison to be sure that an adequate thickness of sample existed below the indentation for valid measurements (fig. 11(b)). Figure 11(b) also shows a 30 percent reduction of wire thickness from the undeformed wire to the deformed wire at crossover.

\section{DISCUSSION}

Debris found in the engine was identified as pieces of the regenerator screens. The magnetic behavior of the debris is explained by the presence of a bcc phase identified by $x$-ray diffraction. The bcc phase was also found in the as received screens. It has been shown by Manjoine (ref. 4) that the bcc phase may be present after plastic deformation by tensile or fatigue loading in Type 304 stainless steel. There is clearly evidence of deformation of the as received screen at crossovers ( $\mathrm{fig}$. 10(a)), which can account for the bcc phase being present.

Several factors are believed to have contributed to the fatigue failures of the screen wires at crossovers. These factors include; reduction of wirc thickness, stress concentration, and highly worked microstructure. The corn bination of the reduction in wire thickness and the ability of the individual screens to move, causes stress concentration at the wire crossovers. The highly worked microstructure was found to have a 65 percent increase in hardness (table I) hence, an easier location for crack initiation and subsequent fatigue failure. 
It was later learned that the reduction in wire thickness occurred because the screen fabricator had subjected each screen to a light cold-roll process. The rolling process had reduced each screen thickness, at the crossovers, from the nominal $82 \mu \mathrm{m}$ design thickness to abut $65 \mu \mathrm{m}$. These dimensional changes were not detected prior to use of the screen, allowing the screens to move freely within the regenerator cavity.

After the regenerator screen failure, a series of diagnostic SPDE tests were performed to determine whether the damaged screens were the cause of the shortfall in SPDE output power. It was found that the power loss could be isolated to the regenerator region, but the specific loss mechanism that caused the reduction in engine power was not defined. However, nearly full engine power recovery has been accomplished by use of a different regenerator matrix and regenerator configuration. The loose-screen matrix was temporarily replaced by a randomly oriented, continuous wire sintered matrix. In addition, a manifold gap was provided between the matrix and the heater and cooler heat exchangers. It is not known at this time to what extent the loose-screen matrix contributed to the power loss.

A new permanent design of the regenerator is now being fabricated with the same Type 304 stainless steel screens sintered together and brazed into a can for insertion into the regenerator cavity as a unit. This new design will prevent individual screen movement, reducing the stress concentration at crossovers. Originally, unsintered screens were chosen over sintered screens because of an expected improvement in performance. Experimental testing of regenerator screens in lower frequency Stirling engines has shown that unsintered screen has better heat transfer and fluid friction characteristics than sintered screen. However, as has been observed, if unsintered loose-screen is used in a regenerator matrix, the screens must be packed tightly together in the regenerator cavity in order to prevent any flexing of the individual screens by the oscillating gas flow.

\section{CONCLUSIONS}

Debris found in the Stirling Space Power Demonstrator Engine was identified as pieces of deteriorated Type 304 stainless steel regenerator screens. Magnetism of the debris was explained by the presence of a body-centered-cubic (bcc) phase introduced by plastic deformation of the screens during fabrication. Fallures of the screens occurred at wire crossovers where there was; 30 percent reduction of wire thickness, stress concentration, and a highly worked microstructure, all of which provided a site for crack initiation and subsequent fatigue failure. A new design of the regenerator uses sintering of the screens into one unit to constrain individual screen movement, thereby reducing stress concentration at crossovers.

\section{REFERENCES}

1. Dochat, G.: Free-Piston Stirling Engines for Space Power. Proceedings of the Twenty-second Automotive Technology Development Contractors Coordination Meeting, SAE P-155, SAE, 1984, pp. 209-216.

2. Walker, G.: Stirling Engines. Oxford University Press, 1980, p. 127. 
3. Nomaguchi, T.: Kazumoto, Y.; and Fujiwara, M.: Determination of the Regenerator Effectiveness of an Actual Stirling Engine. ASME-JSME Thermal Engineering Joint Conference, Y. Mori and W.J. Yang, eds., ASME, 1983, pp. 193-198.

4. Manjoine, M.J.: Westinghouse Electric Corp., Research and Development Center, Personal Communication, April 1986.

5. Spatz, M.W.: Regenerator Matrices for Stirling Engines. Nineteenth Summary Report, Automotive Technology Development Contractors Coordination Meeting, CONF-811090, 1981, pp 240-258.

TABLE I. - MICROHARDNESS ${ }^{a}$ OF AS-RECEIVED

VERSUS RUN-IN-ENGINE SCREEN WIRES

AS SHOWN IN FIGURE 11 (b)

\begin{tabular}{|l|c|c|}
\hline & Undeformed & Deformed \\
\hline As-received & $\mathrm{b}_{258 \pm 24}$ & $452 \pm 28$ \\
Run-in-engine & $251 \pm 20$ & $408 \pm 47$ \\
\hline
\end{tabular}

amicrohardness using a Vicker's indenter and $25 \mathrm{~g}$ load.

bAverage of 15 measurements. 


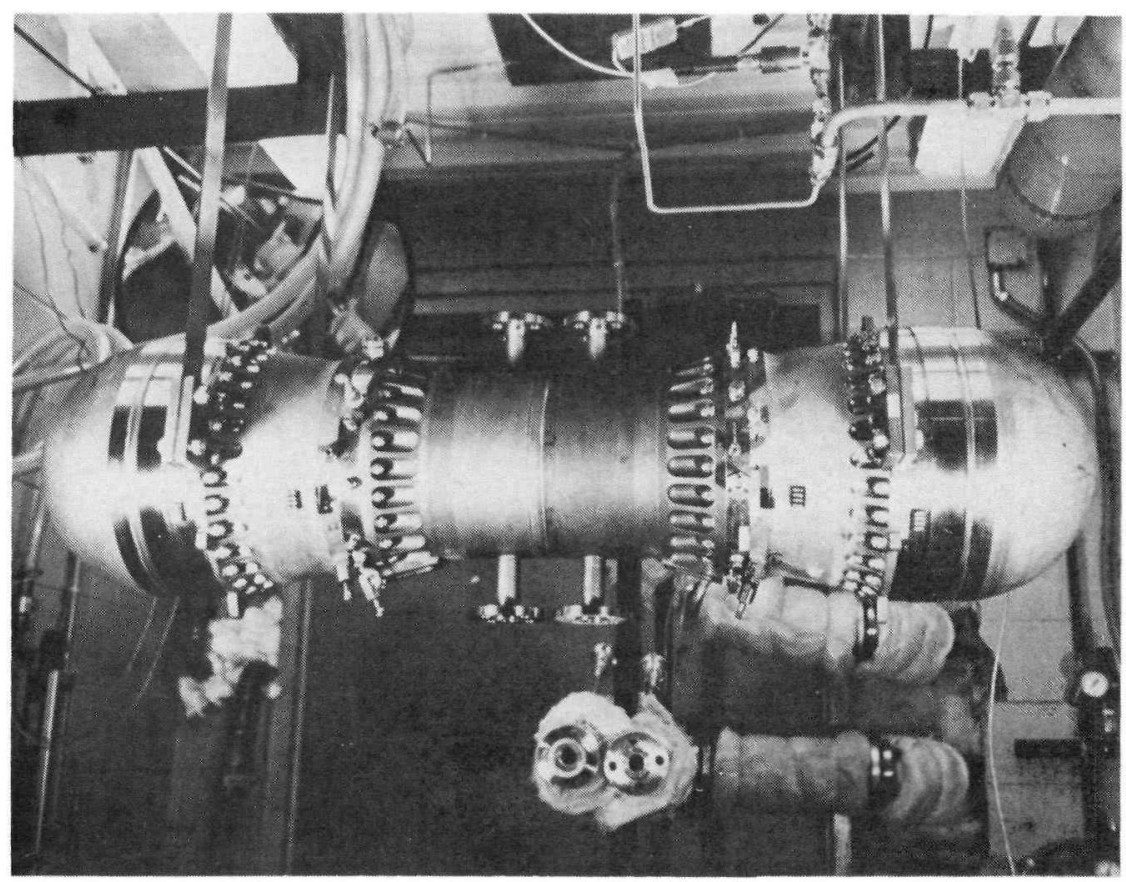

FiguRE 1. - SPACE POWER DEMONSTRATOR ENGINE (SPDE). THE STIRLING ENGINE IS A TWO-CYLINDER, OPPOSED-PISTON/ALTERNATOR CONFIGURATION WITH A LENGTH AND DIAMETER OF 1.25 AND 0.33 METERS RESPECTIVELY.

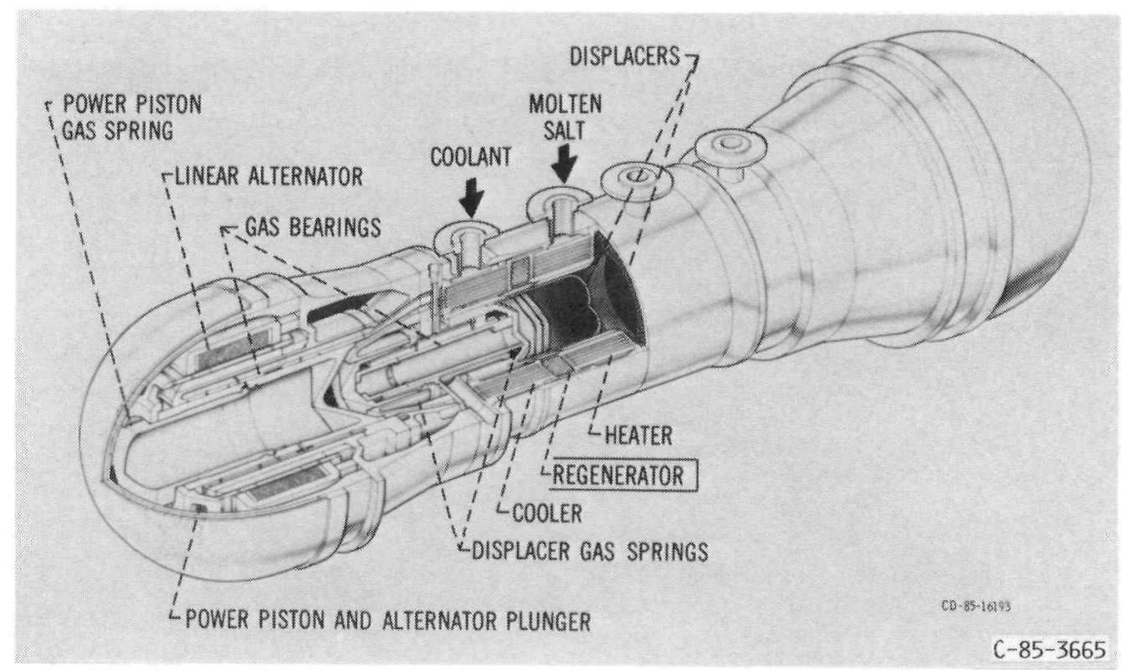

FIGURE 2. - CUTAWAY OF ENGINE SHOWING LOCATION OF REGENERATOR. 


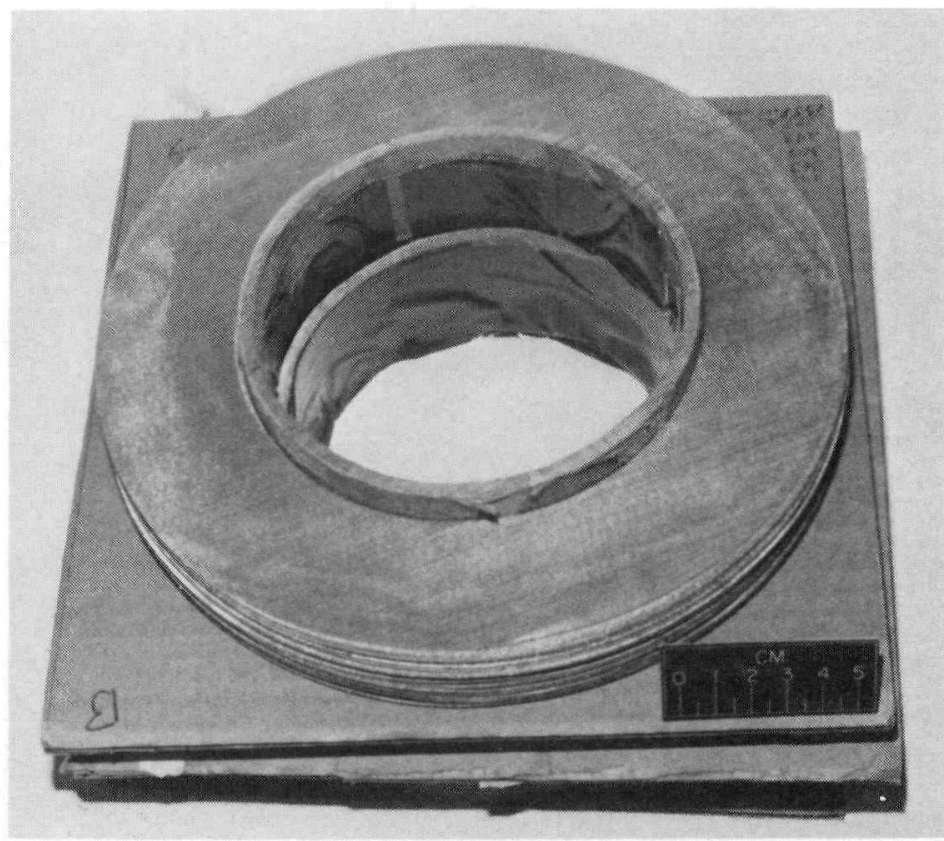

FiguRE 3. - STACK OF 350 TYPE 304 StAinless STEEL REgENERATOR SCREENS.

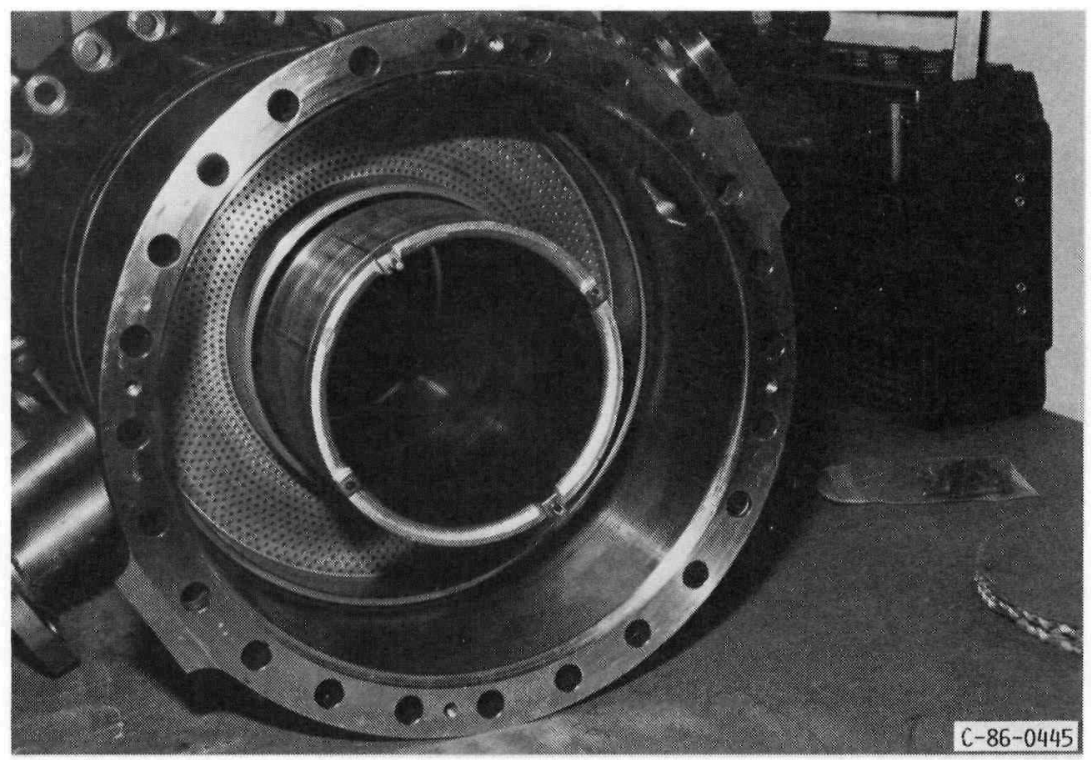

FIGURE 4. - DISASSEMBLED ENGINE SHOWING ANNULAR SPACE AT THE BASE OF THE HEATER WHERE REGENERATOR SCREENS ARE LOCATED. 


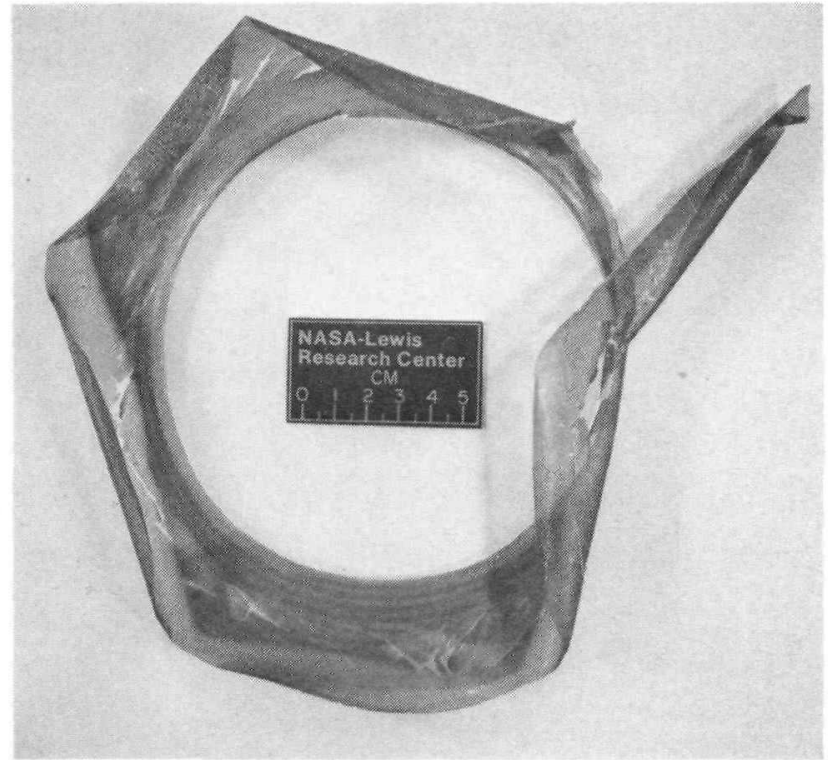

(A) TOP SCREEN (CLOSEST TO HEATER TUBES).

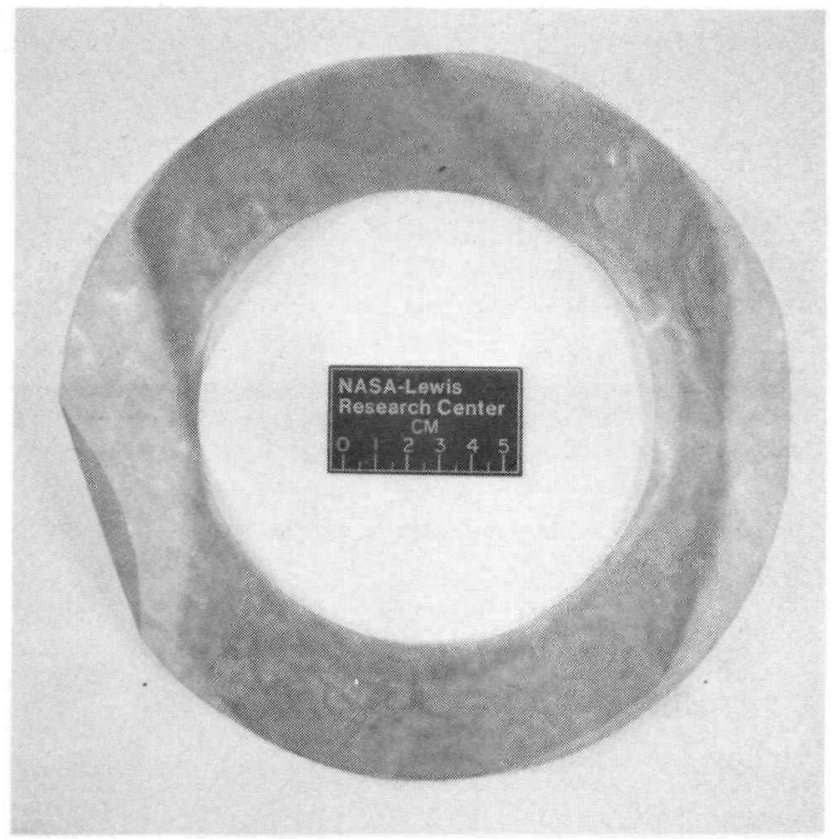

(B) INSIDE SCREEN (ABOUT $2 / 3$ OF THE WAY INTO STACK).

FIGURE 5. - REGENERATOR SCREENS AFTER 80 HOURS OF ENGINE OPERATION. SUBSTANTIAL DAMAGE TO SCREENS IS EVIDENT. 


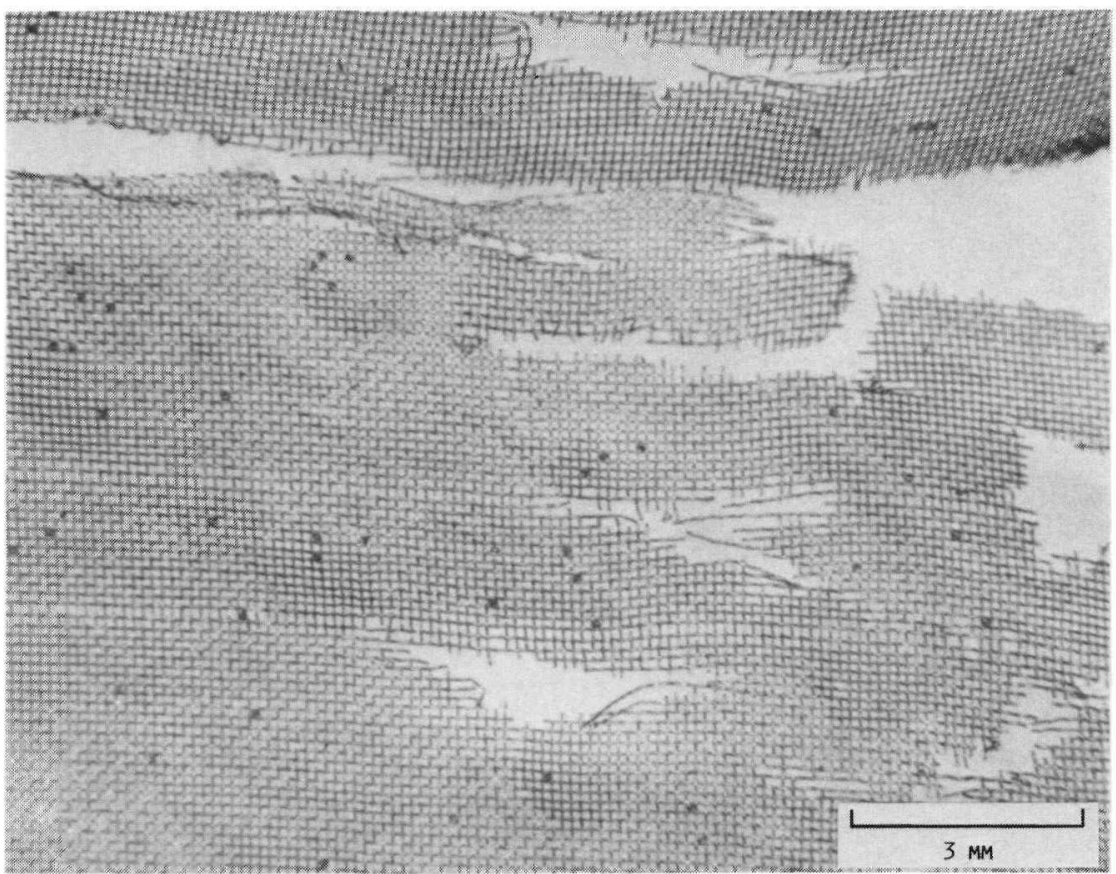

FIGURE 6. - HIGHER MAGNIFICATION OF SCREEN IN FIGURE 5(A). NOTE SEVERE LOSS OF SCREEN WIRES AND PARTICLES FILLING SCREEN OPENINGS. 


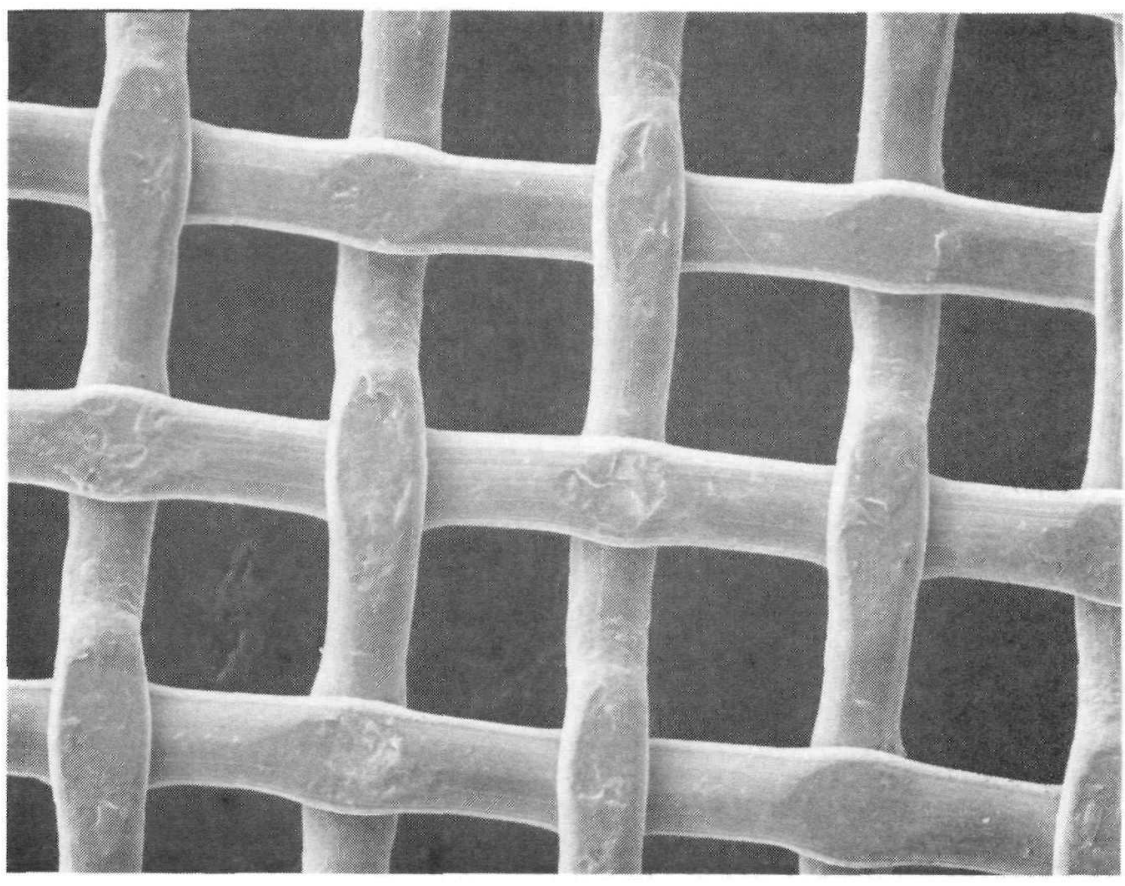

(A) AS-RECEIVED, DEFORMATION AT CROSSOVERS.

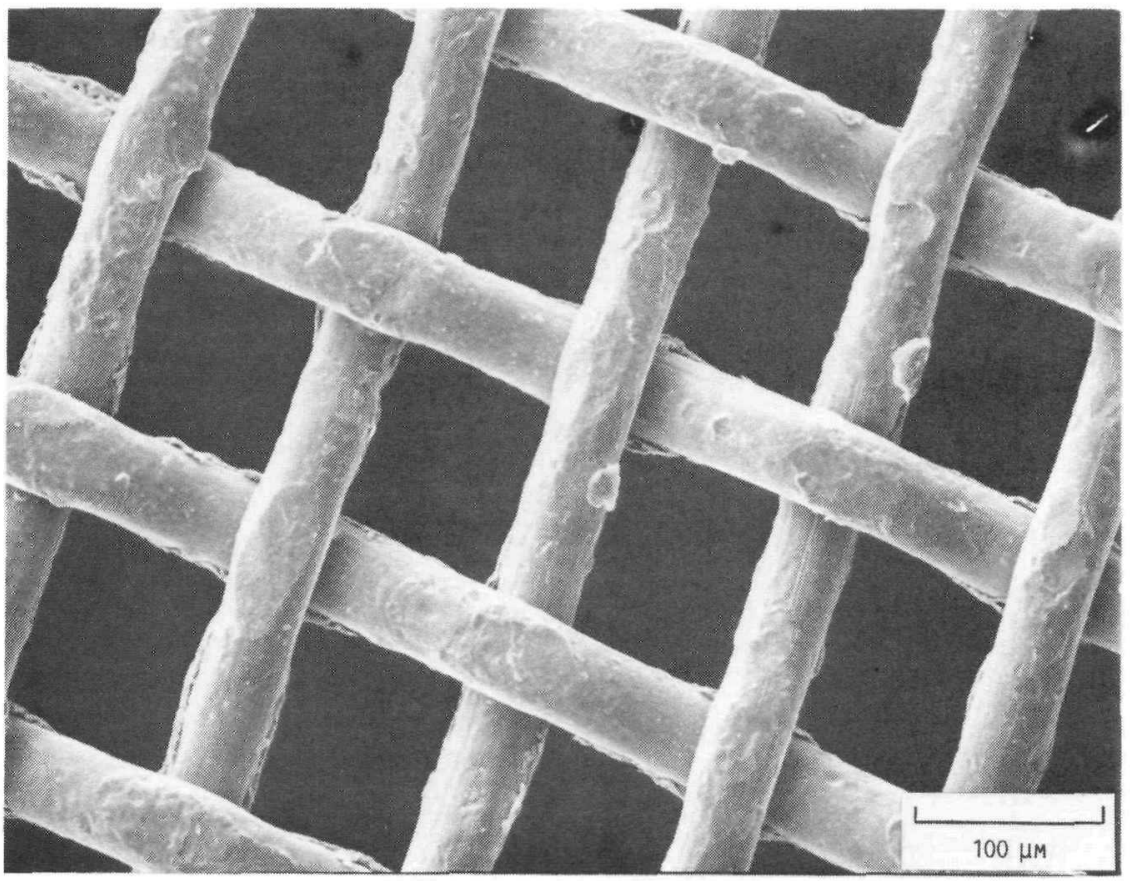

(B) INSIDE SCREEN, SLIGHT DAMAGE.

FIGURE 7. - SCANNING ELECTRON MICROGRAPHS OF REGENERATOR SCREENS. SIGNIFICANT INCREASE IN DAMAGE TO THE WIRES FROM (A) TO (C). FAILURES AT WIRE CROSSOVERS, SMALL CHIPS AND A LARGE PARTICLE CAN BE SEEN IN (C). 


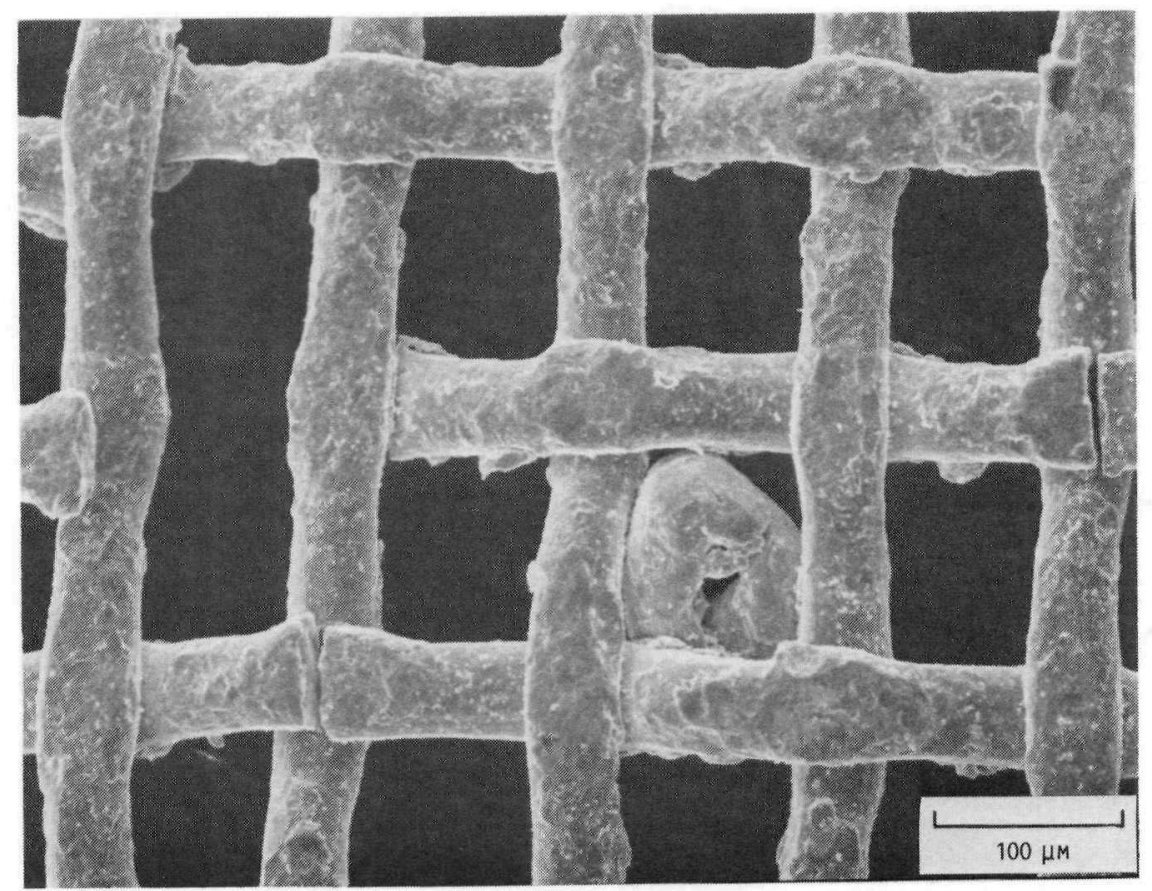

(c) TOP SCREEN, SEVERE DAMAGE.

FIGURE 7. - CONCLUDED. 

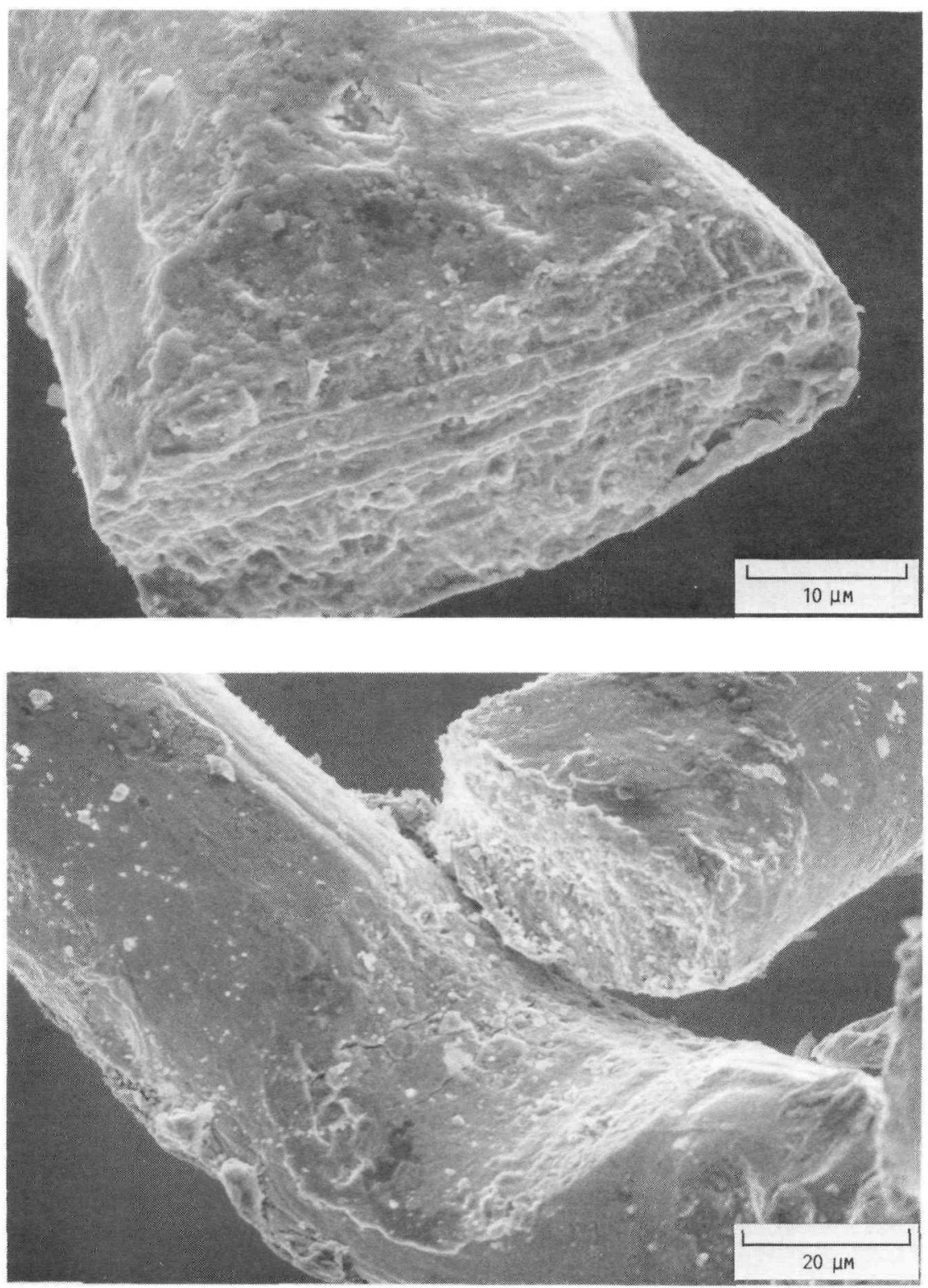

FIGURE 8. - SEM MICROGRAPHS OF ENDS OF FAILED WIRES SHOWING OCCURRENCE OF FAILURE AND CRACKING AT WIRE CROSSOVERS AND FATIGUE STRIATIONS. 

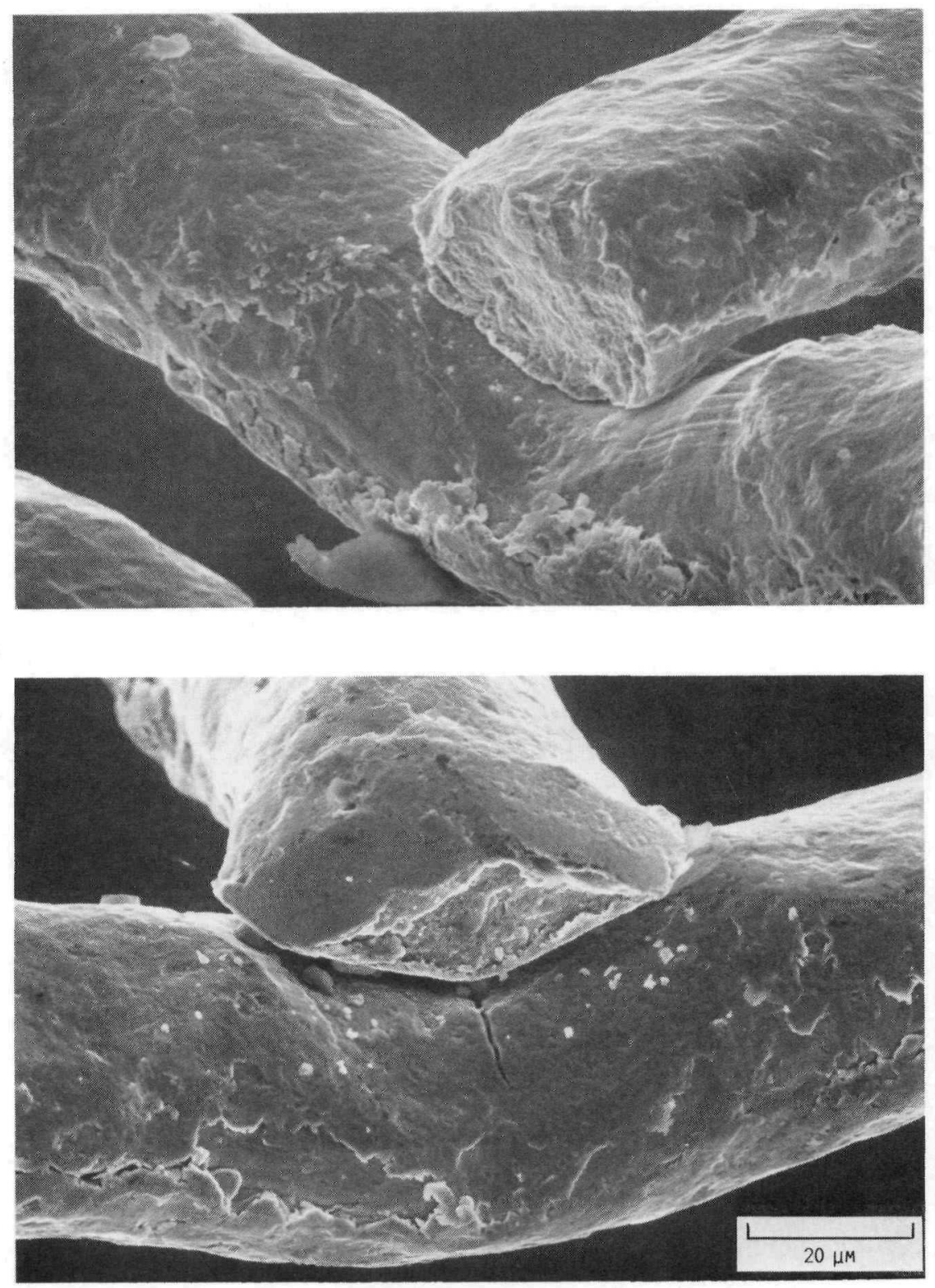

FIGURE 8. - CONCLUDED. 


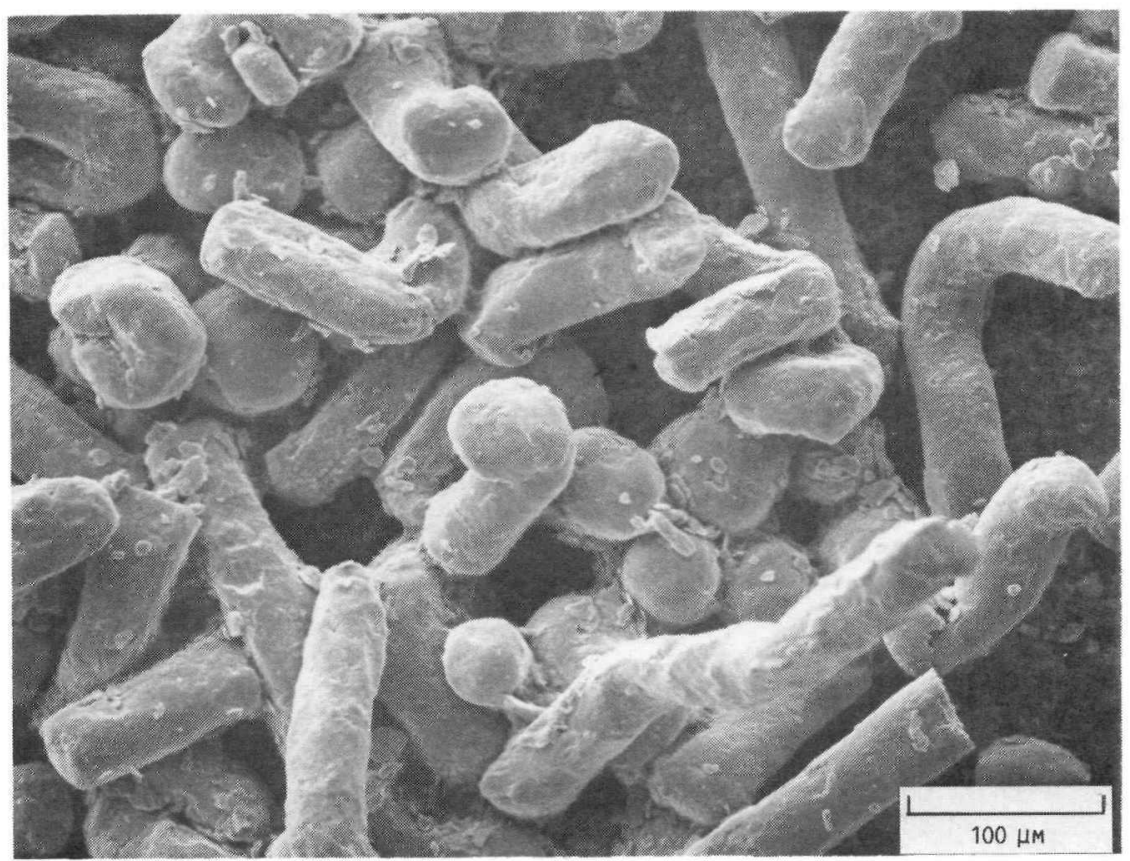

(A) COARSE DEBRIS FOUND BETWEEN SCREENS.

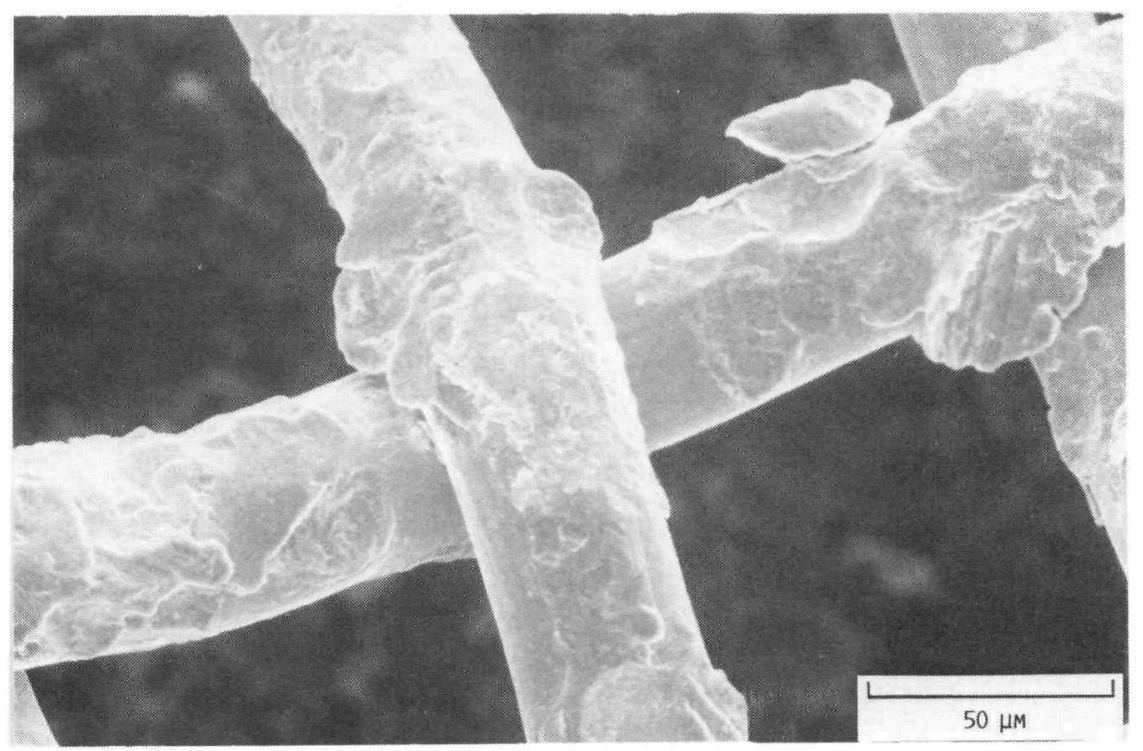

(B) SMALL PIECE OF SCREEN FOUND IN BETWEEN SCREENS.

FIGURE 9. - DEBRIS FOUND IN ENGINE. ALL PARTICLES WERE IDENTIFIED BY XEDS AS TYPE 304 STAINLESS STEEL. THE EXTENSIVE CRATERS IN (B) CORRESPOND WITH THE PARTICLES IN (C). 


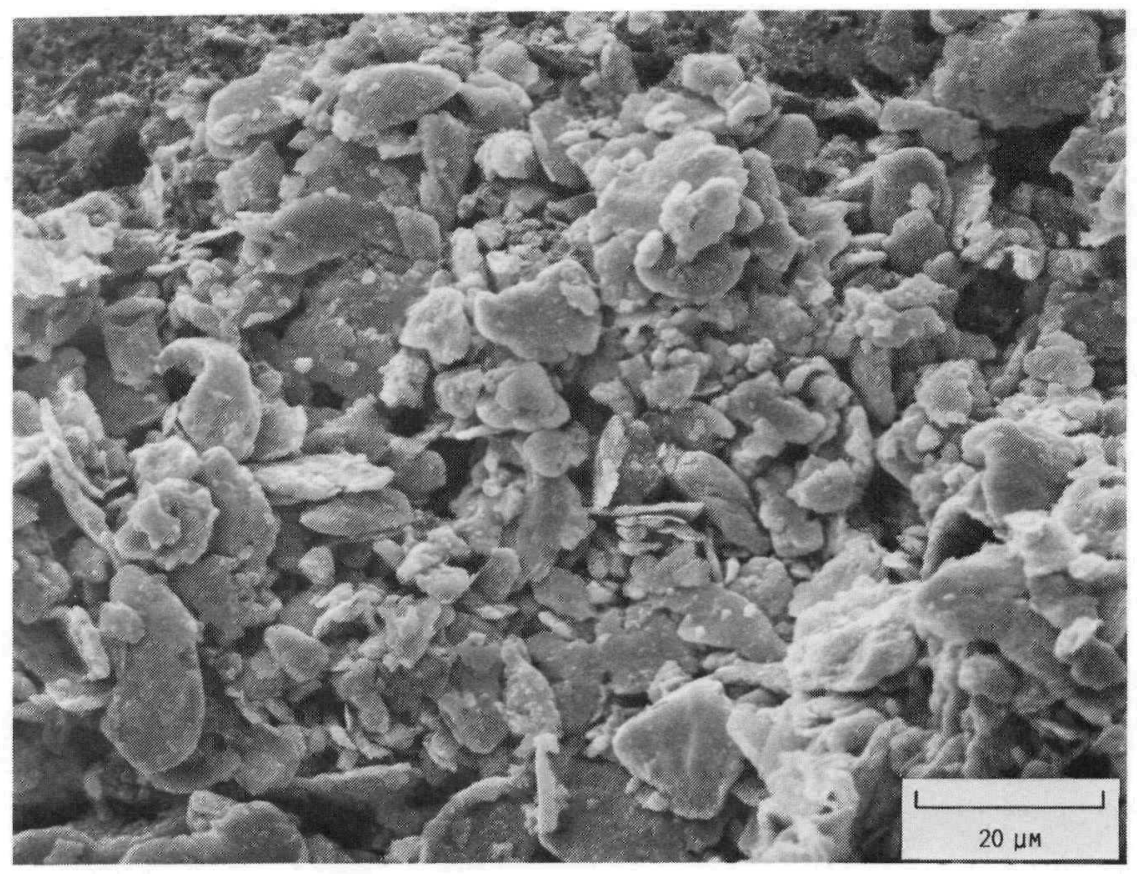

(C) FINE DEBRIS FOUND ON HEATER TUBE SHEET.

FIGURE 9. - CONCLUDED. 


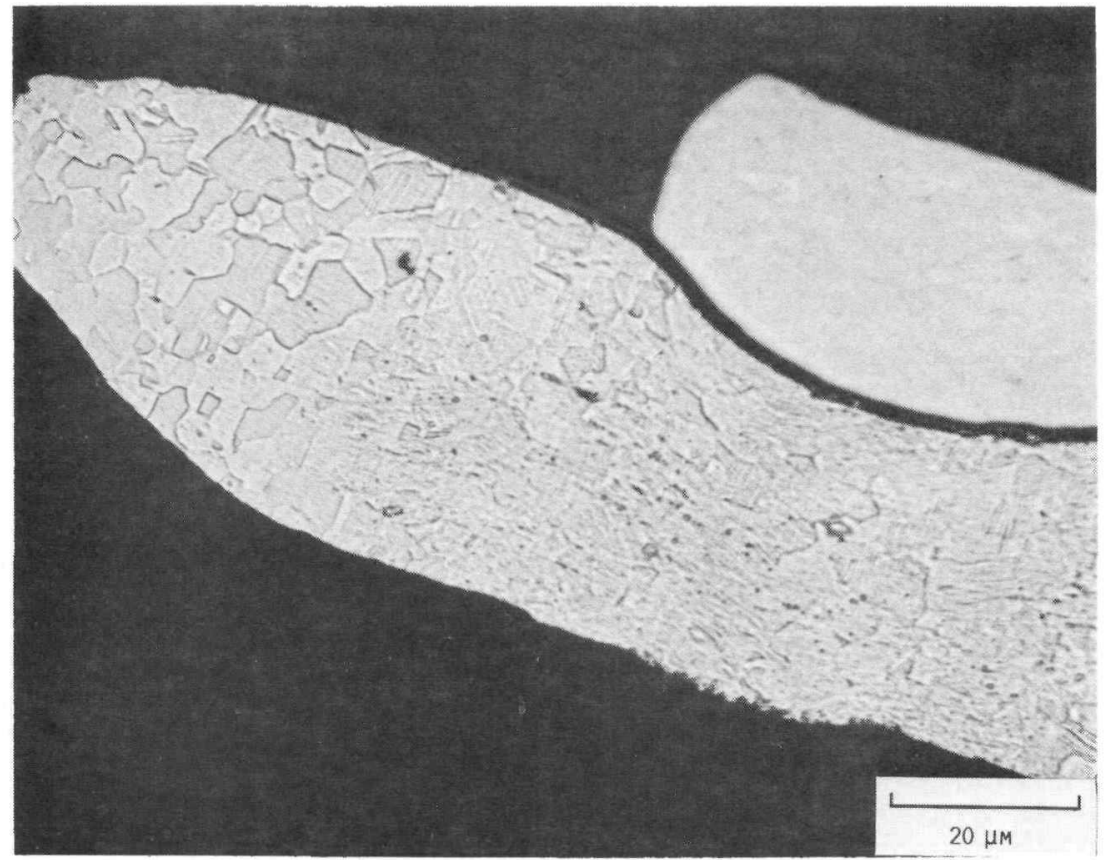

(A) LONGITUDINAL SECTION OF WIRE AT CROSSOVER.

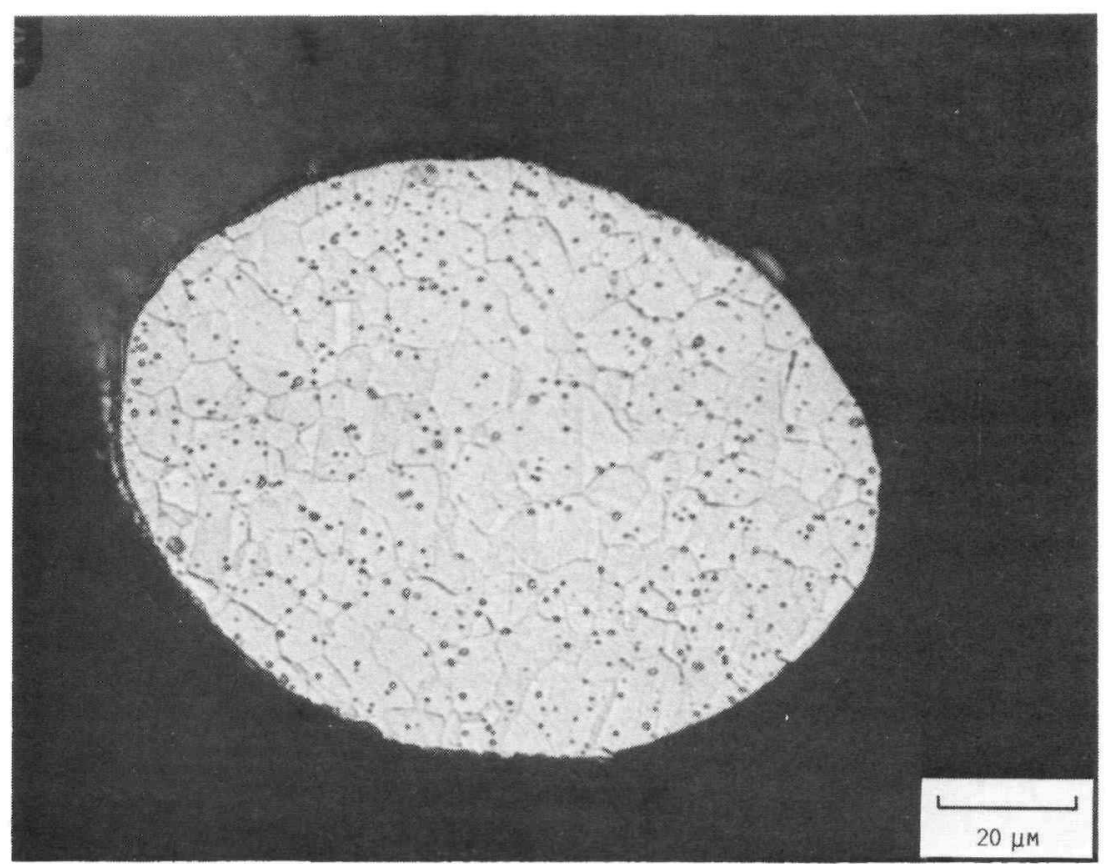

(B) TRANSVERSE SECTION OF UNDEFORMED WIRE.

FIGURE 10. - OPTICAL METALLOGRAPHY OF SCREEN WIRES SHOW A HIGHLY WORKED STRUCTURE AT CROSSOVERS. ETCHED ELECTROLYTICALLY USING 8 VOLTS/1 AMPERE IN A SOLUTION OF 10 PERCENT CHROMIC ACID IN WATER. 


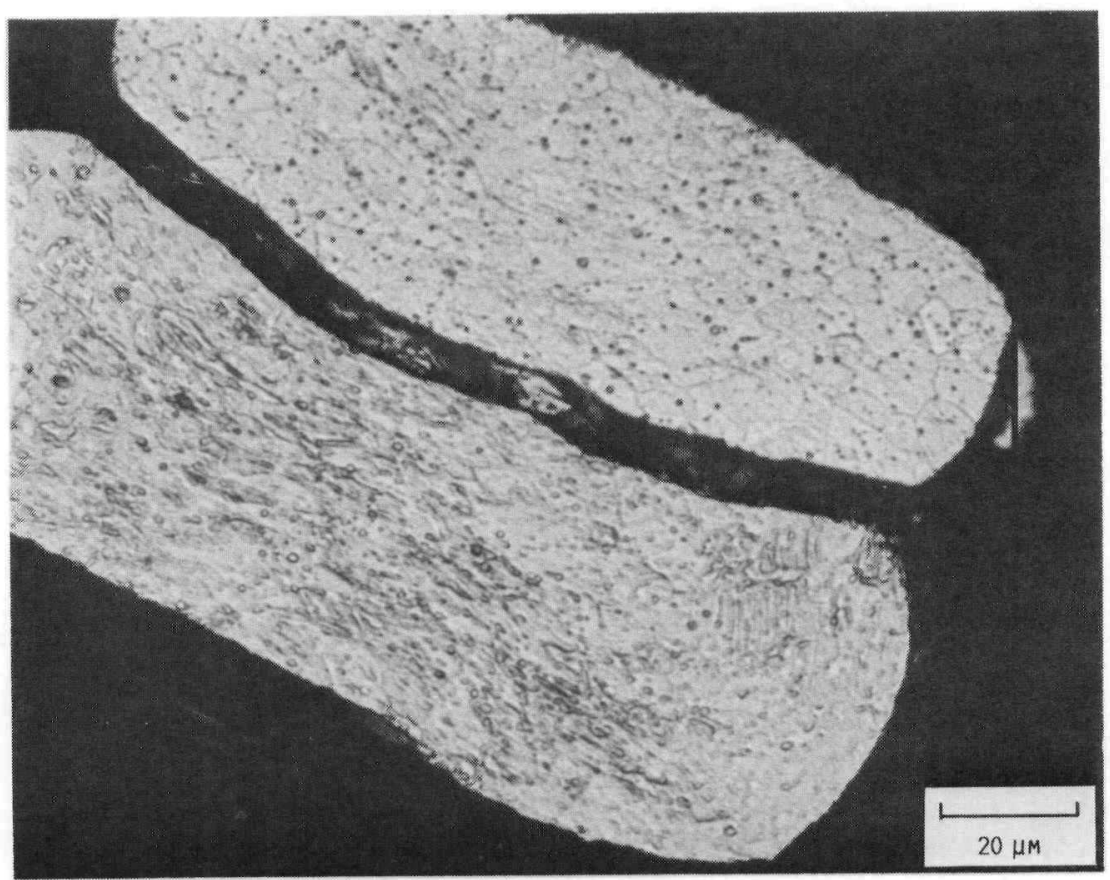

(C) TRANSVERSE SECTION OF DEFORMED WIRE CROSSOVER.

FIGURE 10. - CONCLUDED. 


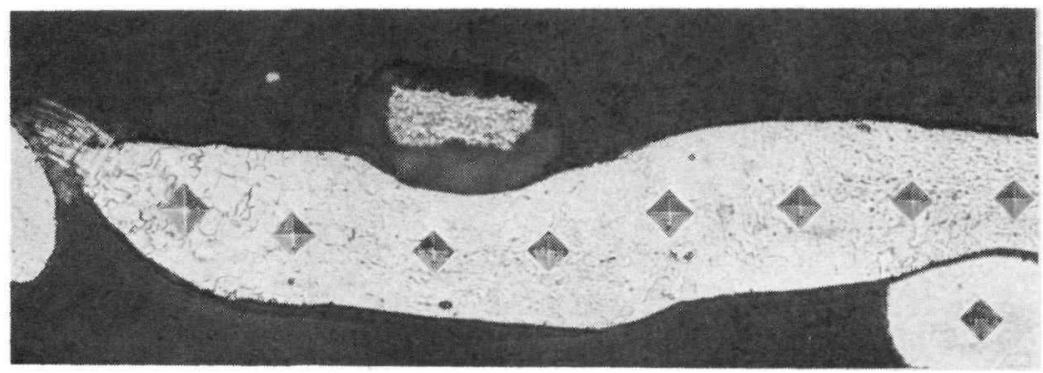

550

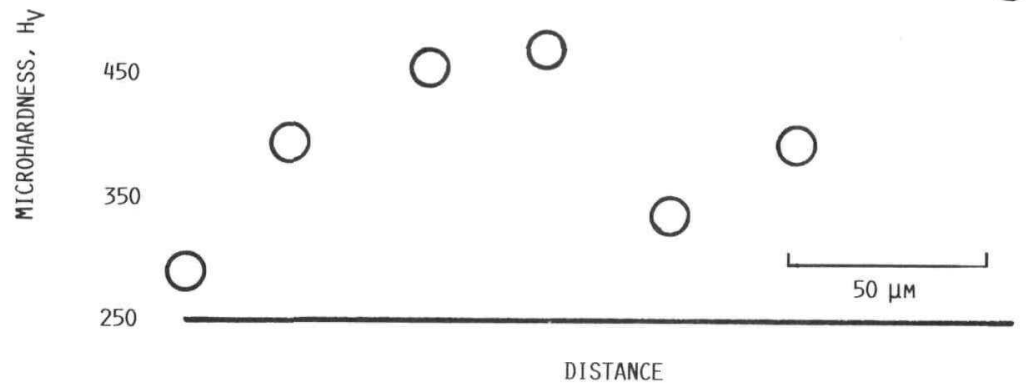

(A) MICROHARDNESS TRAVERSE THROUGH A WIRE CROSSOVER.

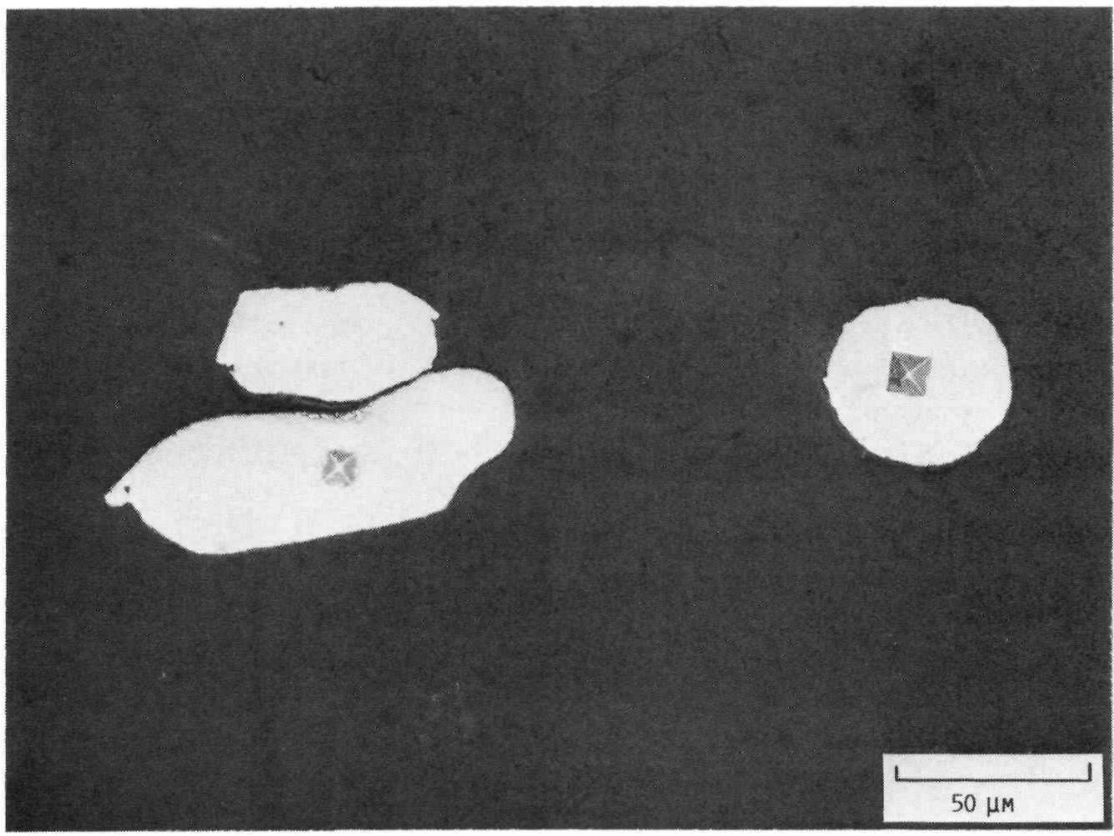

(B) MICROHARDNESS OF A DEFORMED WIRE (AT WIRE CROSSOVER) AND AN UNDEFORMED WIRE.

FIGURE 11. - OPTICAL MICROGRAPHS OF MICROHARDNESS INDENTATIONS SHOW VARIATION OF MICROHARDNESS. 


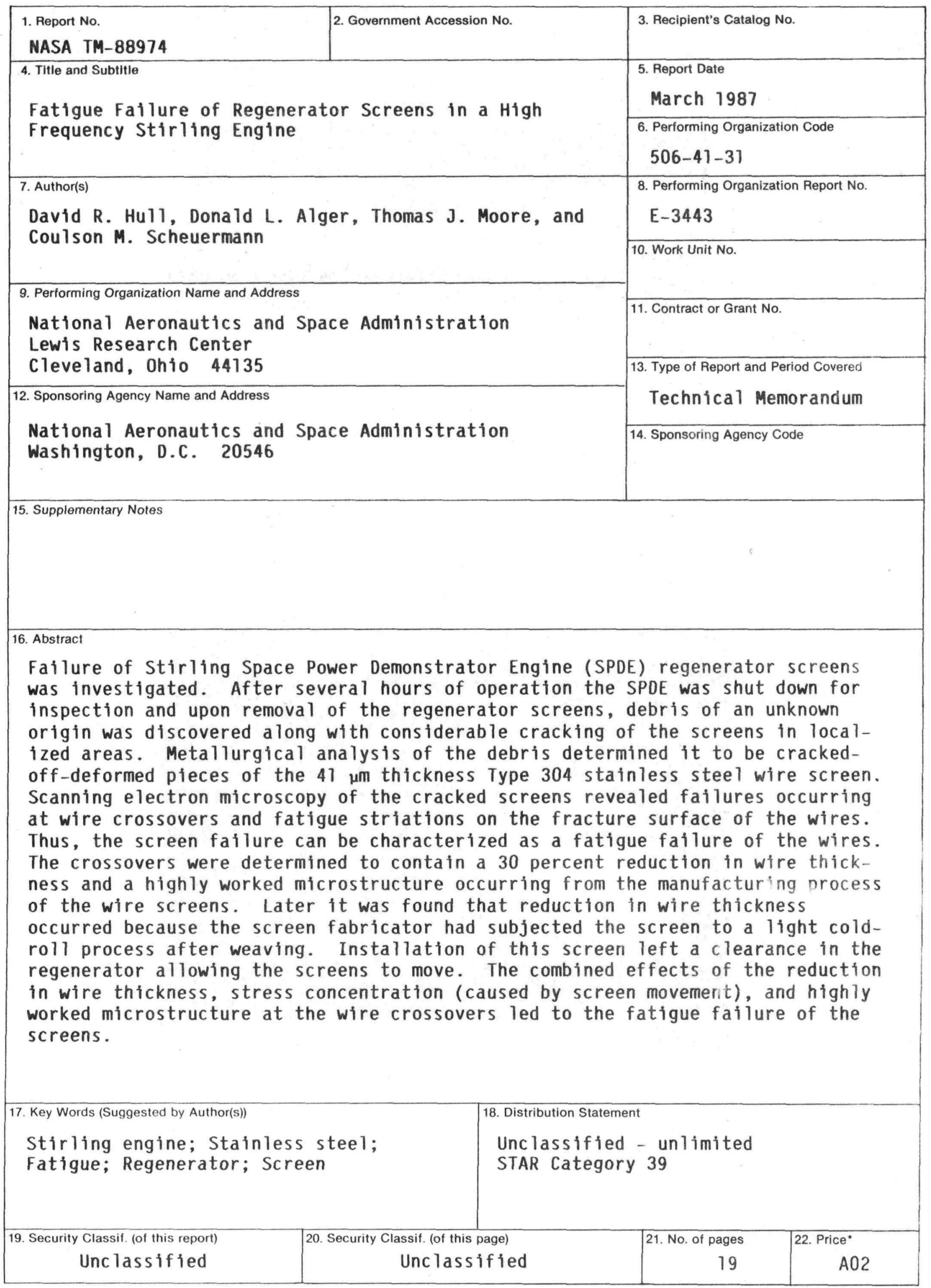

*For sale by the National Technical Information Service, Springfield, Virginia 22161 
National Aeronautics and Space Administration

Lewis Research Center

Cleveland, Ohio 44135

Official Business

Penalty for Private Use $\$ 300$
SECOND CLASS MAIL

ADDRESS CORRECTION REQUESTED

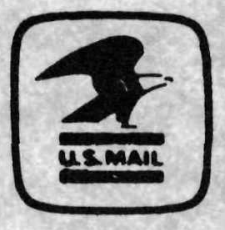

Postage and Fees Paid National Aeronautics and

Space Administration NASA-451 